Przegląd Badań Edukacyjnych Educational Studies Review

ISSN 1895-4308

nr 28 (1/2019), s. 57-75

METAANALIZY

BADAN

EDUKACYJNYCH

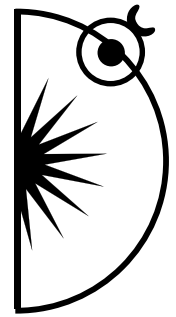

Magdalena Szubielska

ORCID: 0000-0002-8437-0871

John Paul II Catholic University of Lublin; e-mail: magdasz@kul.pl

Anna Szary

Ujazdowski Castle Centre for Contemporary Art in Warszawa; e-mail: a.szary@u-jazdowski.pl

Agata Sztorc

Labirynt Gallery in Lublin; e-mail: agata.sztorc@labirynt.com

\title{
The Influence of Listening to Curatorial Information on Emotions Caused by Artworks, and the Assessment of Contemporary Art by Students. Research in the Space of an Art Gallery
}

http://dx.doi.org/10.12775/PBE.2019.004

\begin{abstract}
The aim of the study conducted in the space of a contemporary art gallery with non-professional participants was to check whether getting familiar with the curator's description influences the emotional reactions caused by the works and their aesthetic evaluation. Hypotheses according to which the viewers who were given the descriptions assessed contemporary art as more fascinating, more understandable, more like a masterpiece, and more preferable (one that they liked more) than viewers who did not know the descriptions, were confirmed. However, the hypothesis that knowledge of curatorial information increases the appreciation of the beauty of contemporary art was not verified positively. Familiarizing with curatorial descriptions influenced one of the five analysed dimensions of emotional reaction induced by watching art - emotional valence, increasing positive feelings in the confrontation with artworks. Conclusions from the conducted research are of a basic nature (refer to the results of previous experiments and include proposals for further empirical studies), as well
\end{abstract}


as an applicational one (they can be used, among others, by an art gallery in the education process).

Key words: contemporary art, psychological aspects of art reception, art gallery context, experimental research, empirical aesthetics, culture of the event.

\section{Introduction}

A society that does not participate in culture has a limited worldview oscillating around the basic needs, with no regard for values. Its main characteristics include the consumption-based attitude to the world, lack of empathy (and, consequently, intolerance towards diversity and views different from their own), sensitivity and altruism (c.f. Szlendak, 2010; Urbanek, 2002). The studies conducted in Poland at the beginning of the 21 st century show that academic youths use culture to a limited extent (Urbanek, 2002). In recent years, the situation seems to be getting worse - instead of using the so-called high culture (which is nowadays used almost exclusively by the so-called prosumers i.e. people who are both producers and consumers of culture), the Polish elite - including students - more often chooses the so-called culture of the event (that could alternatively be called the festival culture or shopping centre culture) that constitutes mainly entrainment and does not incline to intellectual reflections nor gives rise to deep emotional experience (Szlendak, 2010). Szlendak's analysis (2014) demonstrates that art galleries are visited almost exclusively by people with higher education and only when exhibitions are widely promoted and attract a large audience, for example, the Spanish painting exhibition in the National Museum in Wrocław held in 2013. Contemporary art seems to be an area of art in opposition to the culture of event. Indisputably, it is not easy art and plain entertainment is not its main purpose, because it often addresses difficult and controversial social issues (c.f. Żmijewski, 2008). Additionally, its perception requires cognitive engagement, effort and knowledge from the viewer (Leder et al., 2004). Non-expert viewers of art (conclusively, not being art prosumers) are often prejudiced and follow stereotypes with regard to contemporary artists and their work (c.f. Miecznicka, 2015) - mainly due to the lack of its understanding.

When non-professional art viewers are given interpretation guidelines like descriptions or even only titles, their understanding and evaluation of contemporary and modern art increases (Jucker, Barrett, \& Wlodarski, 2014; Millis, 2001; Russell \& Milne, 1997; Russell, 2003; Swami, 2013). Cupchik, Shereck and Spiegel (1994) showed how different types of descriptions have different 
effects on the evaluation of contemporary works of art by non-experts in visual arts. Authors showed the subjects three types of sculpture descriptions: descriptive - enumerating elements of an artwork with their physical characteristics; formal - focused on the structure and inner quality of an artwork; and contextual - giving wider social context to an artwork and stressing its meaning. The aesthetic evaluation of the presented artwork was higher only after reading the contextual description. The research showed that the way in which the interpretation guidelines were given to the viewers was also relevant. It turns out that for non-professional art viewers contemporary paintings are more likeable and cause more positive emotions when the interpretation guidelines are listened to while watching the paintings as compared to when the interpretation guidelines are given before watching the art; at the same time, reading the catalog description by viewers themselves has no influence on the aesthetic evaluation (Szubielska et al., 2018a).

Despite the fact that the art reception studies conducted in laboratory conditions are characterised by low ecological accuracy (Tschacher et al., 2012), the majority of studies on the effects of interpretation guidelines are conducted outside of exhibition areas. Art viewed in its natural context of a gallery or a museum is known to be more attractive and interesting for the viewers and causes a stronger positive emotional reaction than art viewed in laboratory conditions (Brieber, Nadal, \& Leder, 2015; Brieber et al., 2014). Research known to us conducted in a natural context of an art gallery where the positive effect of receiving information about art on the evaluation of an artwork by a contemporary artist was confirmed, was conducted on groups of children (Szubielska, 2018; Szubielska et al., 2018b, 2018c), art experts (Niestorowicz \& Szubielska, in press) and non-professional adult viewers (Cupchik et al., 1994). For preschool and elementary school children, the participation in curator guided tours caused an increased aesthetic preference for figurative art and had no effect on emotions, valence nor the intensity of the experience (Szubielska et al., 2018c). Similar results were obtained in a study on school children visiting an abstract art exhibition. After participating in guided tours, in older children, an increased aesthetic preference for contemporary art was observed and in younger children, the emotional reaction did not change significantly (Szubielska, 2018). Art students who got acquainted with curator's descriptions (read exhibition information materials available in the gallery and took part in a curator-guided tour) evaluated the exhibited artworks as significantly more beautiful, more fascinating and understandable than their colleagues who did not have access to curator's information. However, the assessment of mastery 
of artworks did not differ between the two groups (Niestorowicz \& Szubielska, in press). In the research on a group of students who were not art experts, conducted in a gallery, an influence of descriptions (based on the interviews with artists about their artworks) on aesthetic reactions was observed, specifically on emotional and cognitive reactions and those associated with the recognition of the artwork value (Cupchik et al., 1994).

On the one hand, the emotions experienced in contact with art seem to be less driven by the expertise as compared to aesthetic preference (cf. Leder et al., 2014; Szubielska, Niestorowicz, \& Bałaj, 2016; van Paasschen, Bacci, \& Melcher, 2015). On the other hand, art experts show different emotional reactions in response to contemporary art than amateurs. The reactions of the latter are less moderate. Compared to expert viewers, they feel both stronger negative emotions in confrontation with works having a negative emotional background (e.g. controversial, provocative) and stronger positive emotions in contact with works causing positive affect (Leder et all., 2014). Studies on the influence of providing interpretation guidelines to adult non-professionals on their emotional reactions caused by contemporary or modern art did not give unambiguous results. Some researches show that the emotions of viewers who received information about works do not differ from the emotions of viewers who did not receive such information (Pihko et al., 2011; Szubielska et al., 2016; Szubielska et al., 2018a). However, there are studies that demonstrate that a descriptive title has a negative influence on the viewers' affect (Leder, Carbon, \& Ripsas, 2006) or that it increases the emotional aesthetic evaluation (Cupchik et al., 1994). The above-mentioned studies are difficult to compare because the evaluation of emotional reaction was measured on different scales. Besides, the researchers usually measured emotions on one scale only, which should be considered as a limitation of a study.

According to our knowledge, so far in Poland, there has not been any research conducted in natural conditions (i.e. in an exhibition area of a gallery or a museum) on the influence of relevant information on the emotional reactions and evaluation of artworks by non-professional adult viewers. This research aims to fill this gap and focus on the influence of the curatorial description on emotions (measured in several aspects) caused by viewing art and aesthetic evaluation. In the analysis of the viewers' emotional reactions, the following was taken into account: valence, intensity, dominance, origin and significance of experience (Imbir, 2015). The aesthetic evaluation was measured in aspects previously included in studies on the reception of contemporary art in a gallery (Brieber et al., 2014, 2015; Niestorowicz \& Szubielska, in press), being: beauty, fascination, understanding, mastery, preference. 
The aim of this study is to decide whether the curatorial description influences the emotions of non-professional adult viewers in confrontation with contemporary art in a gallery; and if so, which aspects of the emotional reaction are influenced and how. The research hypotheses were formulated on the basis of the results of previously conducted studies that demonstrated that the aesthetic evaluation of modern and contemporary art is higher with interpretation guidelines provided than without them (Cupchik et al., 1994; Jucker et al., 2014; Millis, 2001; Niestorowicz \& Szubielska, in press; Russell \& Milne, 1997; Russell, 2003; Swami, 2013; Szubielska, 2018; Szubielska et al., 2018b, 2018c). It was predicted that the viewers who received curatorial information would evaluate the artworks as more beautiful (H1), more fascinating (H2), more understandable (H3), more like a masterpiece (H4) and one they like more (H5) than viewers who did not receive curatorial descriptions.

\section{Method}

\section{Participants}

The study involved 50 students of psychology ( 39 women) aged 19 to 24 years $(M=20.54 ; S D=1.31)$. They were invited to participate in the study and were given a choice of four dates (two for each condition - the experimental group with curatorial information and the control group of people without curatorial information) possible for the experiment to be conducted. All participants gave their informed consent to participate in the study.

The participants' knowledge and interest in contemporary art were controlled in a 7-grade interval scales with extremes of "I strongly agree" and "I strongly disagree". The subjects may be considered non-professionals in art because the declared knowledge about art $(M=3.26, S D=1.41)$ and the interest in contemporary art $(M=3.14, S D=1.54)$ were significantly lower than the middle scale result (the results of a one-sample t-test against the predefined value $=4$ were, respectively: $t(49)=-3.71, p=.001$ for knowledge and $t(49)=-3.95, p<.001$ for interest). The subjects in experimental and control groups did not differ significantly in terms of knowledge about art $t(48)=-1.16$, $p=.252$, nor in the level of interest in contemporary art $t(48)=-1.81, p=.076$.

\section{Materials}

The artwork used as stimuli were works of contemporary artists exhibited in Galeria Labirynt in Lublin on an interactive temporary collective exhibition entitled "Skład sztuki" ["Art Ingredients"], exhibited from 26.05.2018 to 
15.07.2018. The exhibition was interactive in the sense that all the pieces could be not only touched but also manipulated with to create new forms. The study used the curatorial information describing each piece (a piece/artwork was understood as a single object, a series of works forming part of a coherent unity or an installation). Descriptions of each work are available in Appendix 1.

For the measurement of emotional reactions caused by each work, the Self-Assessment Manikin was used in the extended version proposed by Imbir (2015). The author complemented the original scales developed by Lang (1980) for the assessment of three dimensions of affective experience: valence (negative versus positive), intensity (tranquillity versus excitation) and dominance (being controlled versus being in control), with additional dimensions: origin (from heart versus from reason) and significance (insignificant versus significant for a person) (Imbir, 2015, cf. Appendix 2).

The aesthetic evaluation of the whole exhibition was measured on a scale between two polar adjectives. The aesthetic experience was evaluated in aspects of beauty, fascination, understanding, mastery, and preference. The extremes of the scale were: ugly - beautiful, repulsive - fascinating, incomprehensible understandable, rubbish- masterpiece, I definitely liked it - I definitely did not like it. The first four scales were used before in studies on the art perception by experts (Niestorowicz \& Szubielska, in press), while the scales similar to the fifth one are widely applied in general population screenings to measure preference and appreciation of artworks (e.g. Brieber et al., 2014, 2015; Jucker et al., 2014).

\section{Procedure}

The experiment took place in a gallery during the "Art Ingredients" exhibition. It was conducted in groups. The participants gave their answers on paper-andpencil questionnaires. The participants appeared on the appointed dates in the gallery and were randomly assigned to two experimental groups: with curatorial descriptions $(N=24)$ or without curatorial descriptions $(N=26)$.

The study began with participants becoming familiar with SAM scales (Imbir, 2015) and the respective instructions (attached as Appendix 2) before entering the exhibition hall. Then, a group of participants was invited to the exhibition, having been previously informed about the interactive type of the exhibition, its title and the permission to touch and alter the exhibits. The viewers watched the artworks under the condition where only the titles were given, or under the condition where they were given the titles of each artwork and additionally they were read the curatorial descriptions. The descriptions may be clas- 
sified as contextual (cf. Cupchik et al., 1994; Appendix 2). After viewing each piece (and under the experimental condition, also after listening to the curatorial description for each piece), the participants were given answer sheets where they wrote the title of an artwork and evaluated it on five 9-point SAM scales of emotions: valence, intensity, dominance, origin and significance of experience. All subjects viewed the artworks in the same order: (1) Stonecznik [Sunflower], (2) O tej porze dnia nawet cienie sq w kolorze [At This Time of the Day Even Shadows Have Colours], (3) Przeplatanie mitości i gniewu [Love and Anger Intertwined], (4) Jak bronić się przed złodziejami księżyca? [ How to Protect Yourself From the Moon Thieves?], (5) Co się w glowie mieści? [What Is in the head?], (6)Witaj, wesota przygodo! [Hello, Fun Adventure!], (7) Połaczenie [Connection], (8) Cyklooksytocyna (Zjednoczone kolory skóry) [Cyclooxitocin (United Colors of the Skin)], (9) Hipnoobrazy [Hypno-Pictures], (10) Strumien' [Stream], (11) Malewicz magnetyczny [Magnetic Malewicz] (information about authors and year of each artwork is included in Appendix 1.) The viewing time was not limited. When all the participants marked the emotions caused by an artwork in the answer sheet, the group proceeded to the next artwork.

After the participants evaluated all 11 pieces of art they were asked to assess the exhibition as a whole on a 7-point interval scales. The participants were requested to reply how they found the exhibition: ugly - beautiful, repulsive - fascinating, incomprehensible - understandable, rubbish (kitsch of no artistic value) - masterpiece (outstanding) and how much they liked it.

The study lasted about 40 minutes.

\section{Results}

Emotions felt in connection with works of art

The analyses were conducted for mean evaluations for all artwork results obtained on each scale of emotional reaction (see Table 1). A t-test for independent samples was performed for each scale individually (with independent variable listening to the curatorial information: yes or no). It was discovered that the curatorial information has a significant influence on the valence of emotions $t(48)=-3.05, p=.004, d=-.86$ - the participants' experiences were more positive when they knew the curatorial information than when they did not know it (see Table 1). Listening to curatorial descriptions did not affect significantly the intensity $t(48)=-.14, p=.889$, dominance, $\mathrm{t}(48)=-1.64, \mathrm{p}=.108$, origin, $t(48)=-.46, p=.651$, nor the significance of experience, $t(48)=-1.43$, $p=.161$. 
Table 1. Emotional reactions to artwork displayed at the exhibition under experimental condition (where the viewers listened to curatorial information) and under control condition (without the information) - descriptive statistics (M - mean and SD - standard deviation) for: valence (negative vs. positive), intensity (tranquility vs. excitation), dominance (being controlled vs. being in control), origin (from heart vs. reason) and significance (insignificant vs. significant)

\begin{tabular}{lcccc}
\hline & \multicolumn{2}{c}{ Curatorial information } & \multicolumn{2}{c}{ No curatorial information } \\
\cline { 2 - 5 } Valence & $M$ & SD & $M$ & SD \\
\cline { 2 - 5 } Intensity & 6.76 & 0.65 & 6.12 & 0.82 \\
Dominance & 5.62 & 0.97 & 5.59 & 0.72 \\
Origin & 6.03 & 1.15 & 5.45 & 1.31 \\
Significance & 4.66 & 0.80 & 4.55 & 0.90 \\
\hline
\end{tabular}

Source: Authors' research.

\section{Evaluation of the exhibition}

Descriptive statistics for the general evaluation of the exhibition are presented in Table 2. Based on t-tests for independent groups it was discovered that the viewers who listened to the curatorial information during their visit in the gallery found the exhibition to be significantly more fascinating, $t(48)=-1.93$, $p=.03, d=-.55$, understandable, $t(48)=-2.81, p=.004, d=-.8$, more of a masterpiece, $t(48)=-2.16, p=.018, d=-.61$, and the one they liked more, $t(48)=-2.69, p=.005, d=-.76$ (see Table 2). Listening to the curatorial information did not significantly influence the evaluation of the exhibition on the scale ugly - beautiful, $t(48)=-1.08, p=.143$.

Table 2. The evaluation of the exhibition under experimental (where the participants listened to curatorial information) and control (no information) condition - descriptive statistics ( $\mathrm{M}$ - mean and SD - standard deviation) for scales: ugly - beautiful, repulsive - fascinating, incomprehensible understandable, rubbish- masterpiece, I do not like it - I like it

\begin{tabular}{lcccc}
\hline & \multicolumn{2}{c}{ Curatorial information } & \multicolumn{2}{c}{ No curatorial information } \\
\hline & $M$ & $S D$ & $M$ & SD \\
\cline { 2 - 5 } Ugly - beautiful & 5.21 & 1.06 & 4.85 & 1.29 \\
Repulsive - fascinating & 5.79 & 1.25 & 5.08 & 1.35 \\
Incomprehensible - understandable & 5.13 & 1.45 & 4.04 & 1.28 \\
Rubbish - masterpiece & 4.79 & 1.22 & 4.08 & 1.13
\end{tabular}


Table 2. cd.

\begin{tabular}{lcccc}
\hline & \multicolumn{2}{c}{ Curatorial information } & \multicolumn{2}{l}{ No curatorial information } \\
\hline I do not like it - I like it & 6.13 & 1.36 & 5.04 & 1.48 \\
\hline
\end{tabular}

Source: Authors' research.

\section{Discussion}

In this study, we aimed to answer questions if and how interpretation guidelines in a form of a curatorial description affect emotional reactions of non-professional adult viewers, specifically Polish students, caused by contemporary art experienced in a gallery; and to verify hypotheses regarding the positive influence of curatorial information on the aesthetic evaluation.

We observed a positive influence of listening to curatorial information while viewing the works on one dimension of the emotional reaction caused by the artwork, being the valence and prompting more positive affect in individuals who knew the curatorial description as compared to those who did not know it. Listening to catalogue descriptions, in turn, did not significantly influence the intensity, origin and significance of experience, nor dominance felt in contact with the artworks. The results of our study partially explain the incoherence in the results of previous experiments (cf. Cupchik et al., 1994; Leder, Carbon \& Ripsas, 2006; Pihko et al., 2011; Szubielska, Niestorowicz \& Bałaj, 2016; Szubielska et al., 2018a) by suggesting that the effect of an interpretation guideline reveals itself in some dimensions of the emotional aesthetic reaction, while not in others. This issue requires further empirical studies.

Hypotheses regarding the positive influence of the curatorial description on increased aesthetic evaluations in the dimension of fascination (H2), sense of understanding (H3), mastery (H4), and preference (H5) were confirmed. The results are consistent with the results of previous studies conducted in a gallery and in a laboratory, with adult and minor viewers, with art experts and non-professional viewers, all of which concluded that the aesthetic evaluation increases with access to some kind of artwork description (Cupchik et al., 1994; Jucker et al., 2014; Millis, 2001; Niestorowicz \& Szubielska, in press; Russell \& Milne, 1997; Russell, 2003; Swami, 2013; Szubielska, 2018; Szubielska et al., 2018b, 2018c). We failed to empirically demonstrate that the viewers with curatorial information evaluate the art as more beautiful than the viewers without this information (H1). Nevertheless, the participants under both conditions, declared the exhibition to be rather beautiful than ugly - which can be seen analysing the descriptive statistics for the dimension of beauty. 
This study has some limitations. The subjects listened to curatorial information read to them aloud while looking at individual artworks displayed at the exhibition. This is a rather uncommon situation that can perhaps occur during a curator-guided tour but usually, the curator would rather talk from memory about the exhibition and reading aloud previously prepared information would be rare. As a rule, visiting a museum or a gallery we read the information about exhibits ourselves or we use the increasingly popular audio guides (Barbieni et al., 2009; Locher, 2011). It would be advisable to verify in future studies if the curatorial information supplied to non-expert viewers in ways other than the one used in this experiment, also influences emotions and aesthetic evaluation.

The second limitation is connected with the nature of the exhibition where the experiment was conducted. The "Art Ingredients" exhibition was designed and intended mainly for children. Despite the fact that it exhibited contemporary art, it was easy, pleasant and with form and content adjusted to children visiting the gallery. Additionally, it was an interactive exhibition allowing visitors to actively participate and interact with artworks through many senses, or even play with art. It can be assumed that it was more entertaining than the majority of exhibitions offered by museums and art galleries. Thus it was closer to the multi-sensual culture of event than traditional art exhibitions (cf. Szlendak, 2010). The visitors, once informed about the possibility to interact with the artworks, enthusiastically followed through. Would the effects observed in this research be confirmed at other, more complicated exhibitions of contemporary art such as conceptual, socially involved or critical art? Is it enough for a nonprofessional viewer to become familiar with a curatorial description in order to become appreciative of works by artists who are widely criticised, for example, Katarzyna Kozyra's (cf. Żmijewski, 2008) or Andres Serrano's art (cf. Leder et al., 2014)? The quest for answers to these questions requires further research that should be performed during traditional art exhibitions in the wide spectrum of topics.

Observations of adult viewers, made by the third co-author of this article during her educational classes accompanying the exhibition, show that some adults, similarly to children, considered the "Art Ingredients" to be a place to have fun. Parents with children built castles using the work of Aleka Polis, tried to put together the weapon by Michał Frydrych or enjoyed bending the artwork of Sarah Evelyn Marsh. Importantly, it was noted that some adults visiting the gallery with their children carefully read the curatorial descriptions placed on the walls. It was also observed that adults visiting the gallery in groups willingly created structures together while the curator talked about certain works. 
In the eyes of adult visitors, the "Art Ingredients" attracted a lot of media attention which is confirmed by a large number of photos posted in social networks, especially photos of works of Aleka Polis and Mateusz Kula. We observed that adults often took the so-called arties (selfies with an artwork) of themselves and their friends which recently became a common behaviour of visitors at exhibition premises (Smith, Smith, \& Tinio, 2017).

In conclusion, the results of this research and observations of participating students allow for a hopeful thought that non-art students, those who are not prosumers,(cf. Szlendak, 2010) can positively react to and appreciate contemporary art. The curatorial information provided to young educated adults, without art expertise, can enhance their positive emotional reactions, understanding, fascination, preference for contemporary art and recognition of its artistic value. Therefore, preparation of exhibition descriptions with interpretation guidelines is worthwhile. It is also worthwhile to convince students to visit galleries of contemporary art and, for example, organise curator-guided tours during student cultural days. Perhaps, gradually, by visiting increasingly intellectually demanding exhibitions that require reflection and cognitive engagement, they will start to appreciate not only entertaining art but also, the so-called, high art.

\section{References}

Barbieri, G., Celentano, A., Orsini, R., \& Pittarello, F. (2009). Understanding art exhibitions: From audioguides to multimedia companions. In: International conference on distributed multimedia systems (pp. 250-256). US: Knowledge Systems Institute Graduate School.

Brieber, D., Nadal, M., \& Leder, H. (2015). In the white cube: museum context enhances the valuation and memory of art. Acta Psychologica, 154, pp. 36-42. DOI: http://dx.doi. org/10.1016/j.actpsy.2014.11.004.

Brieber, D., Nadal, M., Leder, H., \& Rosenberg, R. (2014). Art in time and space: contexts modulates the relation between art experience and viewing time. PLOS ONE, 9(6), e99019. DOI: http://dx.doi.org/10.1371/journal.pone.0099019.

Cupchik, G. C., Shereck, L., \& Spiegel, S. (1994). The effects of textual information on artistic communication. Visual Arts Research, 20(1), pp. 62-78.

Imbir, K. K. (2015). Affective norms for 1,586 polish words (ANPW): duality-of-mind approach. Behavior research methods, 47(3), pp. 860-870. DOI: http://dx.doi.org/10.3758/ s13428-014-0509-4.

Jucker, J.-L., Barrett, J. L., \& Wlodarski, R. (2014). “I just don’t get it”: Perceived artists' 
intentions affect art evaluations. Empirical Studies of the Arts, 32, pp. 149-182. DOI: http://dx.doi.org/10.2190/EM.32.2.c.

Lang, P. J. (1980). Behavioral treatment and bio-behavioral assessment: computer applications. In: J. B. Sidowski, J. H. Johnson, \& T. A. Williams (eds.), Technology in mental health care delivery systems. (pp. 119-137). Norwood, NJ: Ablex.

Leder, H., Belke, B., Oeberst, A., \& Augustin, D. (2004). A model of aesthetic appreciation and aesthetic judgments. British Journal of Psychology, 95(4), pp. 489-508. DOI: http://dx.doi.org/10.1348/0007126042369811.

Leder, H., Carbon, C.-C., \& Ripsas, A. L. (2006). Entitling art: influence of title information on understanding and appreciation of paintings. Acta Psychologica, 121(2), pp. 176-98. DOI: http://dx.doi.org/10.1016/j.actpsy.2005.08.005.

Leder, H., Gerger, G., Brieber, D., \& Schwarz, N. (2014). What makes an art expert? Emotion and evaluation in art appreciation. Cognition \& Emotion, 28(6), pp. 1137-1147. DOI: http://dx.doi.org/10.1080/02699931.2013.870132.

Locher, P. (2011). Contemporary experimental aesthetics: State of the art technology. i-Perception, 2(7), pp. 697-707. DOI: http://dx.doi.org/10.1068/i0449aap.

Miecznicka, M. (ed.) (2015). Sztuka w naszym wieku. Warszawa: Fundacja Sztuki Polskiej ING.

Millis, K. (2001). Making meaning brings pleasure: The influence of titles on aesthetic experiences. Emotion, 1(3), pp. 320-329.

Niestorowicz, E., \& Szubielska, M. (in press). Wpływ deskrypcji dzieła sztuki na jego percepcję. Logopedia.

Pihko, E., Virtanen, A., Saarinen, V.-M., Pannasch, S., Hirvenkari, L., Tossavainen, T., Haapala, A., \& Hari, R. (2011). Experiencing art: the influence of expertise and painting abstraction level. Frontiers in Human Neuroscience, 5:94. DOI: http://dx.doi.org/10.3389/ fnhum.2011.00094.

Russell, P. A. (2003). Effort after meaning and the hedonic value of paintings. British Journal of Psychology, 94(1), pp. 99-110. DOI: http://dx.doi.org/10.1348/000712603762842138.

Russell, P. A., \& Milne, S. (1997). Meaningfulness and the hedonic value of paintings: effects of titles. Empirical Studies of the Arts, 15(1), 61-73. DOI: http://dx.doi.org/10.2190/ EHT3-HWVM-52CB-8QHJ.

Smith, L. F., Smith, J. K., \& Tinio P. P. L. (2017). Time spent viewing art and reading labels. Psychology of Aesthetics, Creativity, and the Arts, 11(1), pp. 77-85. DOI: http://dx.doi. org/10.1037/aca0000049.

Swami, V. (2013). Context matters: Investigating the impact of contextual information on aesthetic appreciation of paintings by Max Ernst and Pablo Picasso. Psychology of Aesthetics, Creativity, and the Arts, 7(3), pp. 285-295. DOI: http://dx.doi.org/10.1037/a0030965. 
Szlendak, T. (2010). Wielozmysłowa kultura iwentu. Skąd się wzięła, czym się objawia i jak w jej ramach ocenić dobra kultury? Kultura Współczesna, 4(66), pp. 80-97.

Szlendak, T. (2014). Formy aktywności kulturalnej. In: K. Czerniejawska (ed.), Praktyki kulturalne Polaków (pp. 151-219). Toruń: Wydawnictwo Naukowe Uniwersytetu Mikołaja Kopernika.

Szubielska, M. (2018). Wpływ zajęć edukacyjnych prowadzonych w galerii na odbiór abstrakcyjnej sztuki współczesnej przez uczniów młodszych klas szkoły podstawowej. Przegląd Badań Edukacyjnych, 26(1), pp. 21-44. DOI: http://dx.doi.org/10.12775/ PBE.2018.002.

Szubielska, M., Francuz, P., Niestorowicz, E., \& Bałaj, B. (2018a). The impact of reading or listening to a contextual information relating to contemporary paintings on the evaluation by non-experts in the field of art. Polskie Forum Psychologiczne, 23(3), pp. 610-627. DOI: http://dx.doi.org/10.14656/PFP20180309.

Szubielska, M., Niestorowicz, E., \& Bałaj, B. (2016). Wpływ figuratywności obrazu i informacji katalogowej na percepcję estetyczną malarstwa współczesnego przez ekspertów i laików. Annales Universitatis Paedagogicae Cracoviensis. Studia Psychologica, 9, pp. 21-34.

Szubielska, M., Ratomska, M., Wójtowicz, M., \& Szymańska,A. (2018b). Effect of educational workshops in an art gallery on children's evaluation and interpretation of contemporary art. Empirical Studies of the Art. DOI: http://dx.doi.org/10.1177/0276237418790917.

Szubielska, M., Wójtowicz, M., Szymańska, A., Ratomska, M., \& Sztorc, A. (2018c). Ocena estetyczna sztuki współczesnej przez dzieci przedszkolne i wczesnoszkolne. Edukacja, 2(145), pp. 43-63. DOI: http://dx.doi.org/10.24131/3724.180203.

Tschacher, W., Kirchberg, V., van den Berg, K., Greenwood, S., Wintzerith, S., \& Tröndle, M. (2012). Physiological correlates of aesthetic perception of artworks in a museum. Psychology of Aesthetics, Creativity, and the Arts, 6(1), pp. 96-103. DOI: http://dx.doi. org/10.1037/a0023845.

Urbanek, J. (2002). Uczestnictwo młodzieży akademickiej w kulturze. Kraków: Wydawnictwo Naukowe Akademii Pedagogicznej.

van Paasschen, J., Bacci, F., \& Melcher, D. P. (2015). The influence of art expertise and training on emotion and preference ratings for representational and abstract artworks. PLoS ONE, 10(8): e0134241. DOI: http://dx.doi.org/10.1371/journal.pone.0134241.

Żmijewski, A. (2008). Drżące ciała. Rozmowy z artystami. Warszawa: Wydawnictwo Krytyki Politycznej. 


\section{Acknowledgements}

We want to thank Dr Kamil Imbir for the pictorial SAM scales with instructions he made available to us. We are also very grateful for all the help and the possibility to use the exhibition premises of Galeria Labirynt in Lublin for the purpose of our study.

\section{Appendix 1. Curatorial descriptions of artworks presented at "Art Ingredients" exhibition.}

\section{Basia Bańda and Tomasz Relewicz, Stonecznik [Sunflower] (2018)}

There is a rock formation called Sunflower in the higher part of Karkonosze. It is a hill that survived erosion by wind and rain made of several cracked granite monadnocks. Sunflower is the most famous and best visible rock formation in Karkonosze. Its unique shape is the effect of a very slow and natural weathering process where elements less resistant to weather conditions are gradually removed and the solid rock remains.

Sunflower rises up to the sky like a flower but it is not the real origin of the rock's name. It comes from the times when the locals could tell it was noon when the sun was up above the rock. The work of Basia Bańda and Tomek Relewicz is composed of several elements of different shapes, just like the Sunflower rock. They can be freely combined to create your own rock formations. They are connected by magnets, just as in the Solar system, the Sun in the centre and celestial bodies are bound by gravitation.

Alicja Bielawska $O$ tej porze dnia nawet cienie sa w kolorze [At This Time of the Day Even Shadows Have Colours] (2018)

The light lets us see the colours. We can see how different a colour is in natural or artificial light and depending on the time of the day. Each of us sees colours differently. We have different associations with each colour depending on our memories.

Alicja Bielawska wanted to literally immerse herself in colours so she created spaces inviting visitors to stay among colours. Using thin fabrics gently transmitting light the artist separated circular rooms. Those small spaces with waving walls give visitors the chance not only to see but to feel the colour as well.

The colours may be as fleeting as light or as palpable as the texture of the fabric. The colours of hanging fabrics are matched with mattresses where visitors may sit or rest or move around to see how the colours interact, attract or repel each other. 


\section{Zuzanna Czebatul, Przeplatanie milości i gniewu [Love and Anger Inter- twined] (2017)}

They say there is a thin line between love and hatred. These two feelings can intertwine and sometimes it is hard to say if we would like to hug, or rather kick a person. Zuzanna Czebatul, the artist, illustrated this relationship with objects that are soft in touch and shaped like human arms and feet. Intertwined they create a composition where it's impossible to tell upper and lower limbs apart. We can manipulate them as we wish; give high-five or get a hug and become lost in the tangle of nice shapes.

\section{Michał Frydrych Jak bronić się przed ztodziejami księżyca? [How to Protect Yourself From the Moon Thieves?] (2018)}

If there is one thing we are born with, it must be the unrestricted ability to create and abandon imaginary worlds. The younger we are, the better we are at it. We easily jump between the roles, from lion tamers to space conquerors. We tend to live in worlds magically created by books, films, and computer games. And we change the realms as easily as others change socks. However, it does not last forever. The world mischievously deprives us of the freedom we are born with and, before we know, we become prisoners of one common reality with processes beyond our control. Freedom must be protected!

Michał Frydrych gives us the gun to arm us for the fight. The enlarged and disassembled to dozens of parts Beretta 92 FS model is painted in cheerful colours. Girls and boys, women and men, all can play with it. You can do with it anything your imagination tells you to; build a skyscraper, igloo, barricade, canoe or threaten the moon thieves. It's an experiment. We'll see if it works.

\section{Barbara Gryka, Co się w glowie mieści? [What Is in the Head?] (2018)}

The artist seeks to understand how children perceive emotions. Do they understand what is happening to them when they feel grief, joy, or anger? During the exhibition, the children will illustrate pairs of emotions. They will create portraits of abstract concepts. At the end of the exhibition, the artist will make soft toys according to children's works.

This artwork is a kind of an experiment that Gryka wants to conduct at the exhibition. She will verify if all children perceive emotions in similar ways and if it is possible to recreate them in a visual shape.

Mateusz Kula, Witaj, wesota przygodo! [Hello, Fun Adventure!] (2018)

When you leave the room, you enter the backyard; and going back - when 
you leave the backyard, you enter the room. Mateusz Kula's installation is a combination of the two spaces. It contains elements taken from the reality and transformed by the artist: enlarged balls from children toys, a twisted carpet rack, a bed or a mysterious balcony protruding from the wall. All elements are tightly covered with wallpapers with enlarged graphics taken from computer and role-play games. These are not specific shapes but rather small abstract parts of graphics from gaming magazines like "Secret Service", "Gambler", and "Magia i Miecz" ["Magic and Sword"], etc.

A collection of costumes supplements the installation. Wearing them, the visitors become part of the installation and their activity complements the space designed by the artist.

\section{Sarah Evelyn Marsh, Polaczenie [Connection] (2018)}

Each of us has drawn at least one line in our lifetime. Perhaps it was a straight line or a swirl, thick or thin, a careless scribble or a careful work. What would happen if a flat line went into space? Would it still retain all its properties?

Sarah Evelyn Marsh encourages you to enter into an artwork and experience the spatial lines with your hands and feet and skin. You can move the objects and change their form and shape. What happens to them then? Do they become part of your body, an additional element or your safe shelter? Each object has its unique texture, colour, and smell. It takes time to test all the options. The photographs can be seen as tips and inspirations to create your own layouts and meanings.

\section{Aleka Polis, Cyklooksytocyna (Zjednoczone kolory skóry) [Cyclooxitocine (United Colors of the Skin)] (2007-2018)}

The idea was born during the scholarship in Stockholm in 2007 at the Day of Languages. Four colours symbolise four skin colours which stand for the multiculturalism of the modern society and intertwining cultures. A tower and a mural - guards of the right to freedom for all the people regardless of skin colour, political views, origin and religion.

Each cube is half the volume of the previous one. Towards the end, they have almost the same colour. Four squares (in the two-dimensional version) or cubes (in the three-dimensional version) are the beginning and the base of this form. The form has its beginning but no end. The base can be endlessly divided by adding ever smaller modules.

This form was displayed during the Podażaj za bialym królikiem [Follow the White Rabbit] exhibition in Bunkier Sztuki in 2010 and in Museum am Ostwall in Dortmund in 2012 as a spatial model with four divisions with an infinite number of them. 
Kamil Stańczak, Hipnoobrazy [Hypno-Paintings] (2018), Stumień [Stream] (2018), Malewicz magnetyczny [Magnetic Malewicz] (2018)

The hypnotic, rotating images are inspired by a simple observation of sunrises and sunsets. The immovable orange dot symbolises the central star of the Solar system with geometric shapes rotating around it like parts of the landscape. The starting point of the perfectly traditional painting on canvas was a digital camera picture. The artist creates pairs of almost identical images with slight differences in small elements. Starting with the observation of nature, the artist simplifies the landscape, transfers it on canvas and sets it in motion resembling the moving image on a telephone or camera screen.

A similar principle is used in the painting machine - Strumien. It is a recording of the paint dripping off a wall or the painting process illustrated by the special construction of several dozen colourful spots.

Malewicz magnetyczny invites to play with a reproduction of a painting by the famous avant-garde artist. Stańczak notices a certain similarity of colour elements on Malewicz's paintings with simple children puzzles and illustrations and invites viewers to create their own version of the painting. 


\title{
Appendix 2. SAM scales used to measure emotions with instructions for participants
}

Emotional valence: negative vs. positive

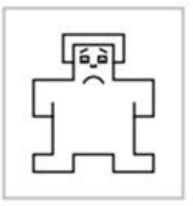

12

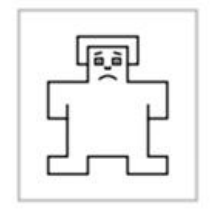

3

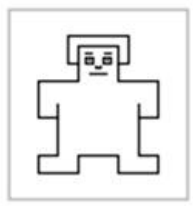

4

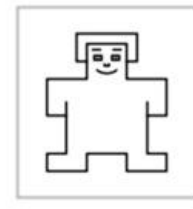

$7 \quad 8$

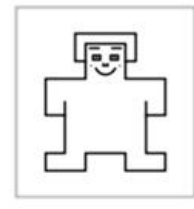

9

"The first picture shows a definitely dissatisfied person who can be described by feelings like panic, irritation, disgust, despair, defeat, or crisis. The last picture shows a definitely happy person who can be described by feelings like fun, pleasure, happiness, relaxation, satisfaction, or leisure".

Intensity of experience: tranquility vs. excitation

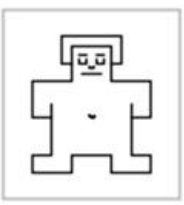

1

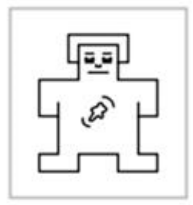

2

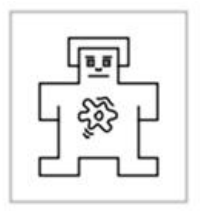

5

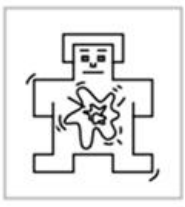

7

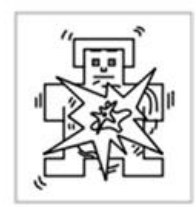

8

9

"The first picture shows a very calm almost sleeping person who can be described by feelings like relax, tranquillity, immobility, thoughtfulness, boredom, or laziness. The last picture shows a person torn by excitement who can be described by feelings like excitation, euphoria, arousal, fury, distress, or rage"

Sense of dominance: being under control vs. being in control.
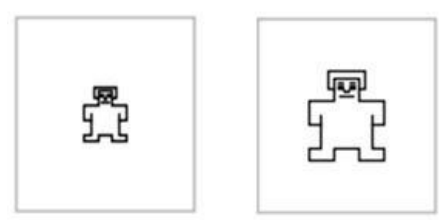

1

2

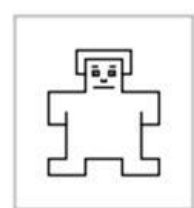

4

\begin{abstract}
5
\end{abstract}

\begin{abstract}
6
\end{abstract}

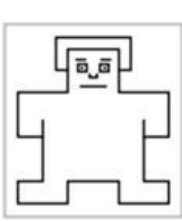

7

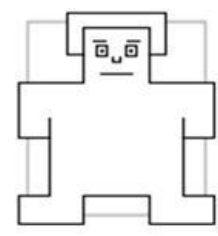

8 
"The first picture shows a person who feels lack of control and empowerment and can be described by feelings like submission, intimidation, enslavement, withdrawal, subjection, or surrender. The last picture shows a dominating person in control of a situation who can be described with feelings like control, influence, importance, dominance, recognition, or decisiveness."

Origin of experience: from heart vs. from reason

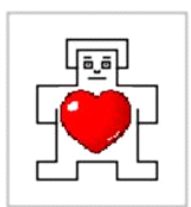

1

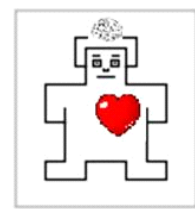

2

3

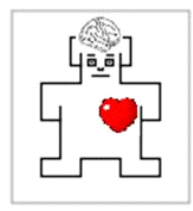

5

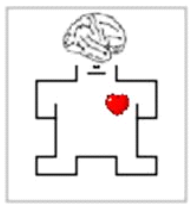

7

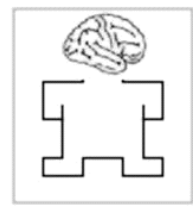

9

"The first picture shows a person overwhelmed by the law of heart and can be described by feelings like unstoppability, total commitment or related with full engagement, impulsiveness, spontaneity, no hesitation. The last picture shows a person overwhelmed by the reason who is reflexive and can be described by feelings that result from thinking, planning, contemplation, prediction, choices, or comparison."

Significance of experience: insignificant vs. significant for a person

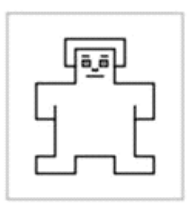

1

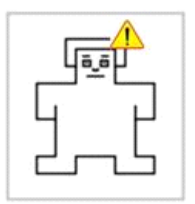

2

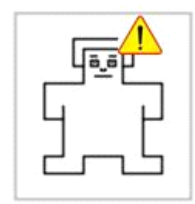

5

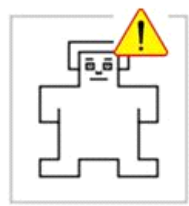

7

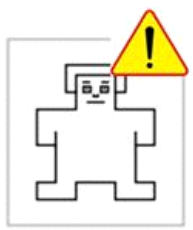

9

"The first picture shows a person who considers his own emotions as irrelevant for his goals, plans and expectations. His experience may be described as trivial, unnoticed, fleeting, unimportant, insignificant, meaningless. The last picture shows a person who considers his own emotions as definitely relevant for his goals, plans and expectations. His experience may be described as meaningful for his life, significant, turning points, vital, important, or decisive." 